\title{
APPLICATION OF TECHNICAL TEXTILE IN MEDICINE
}

\author{
Silvana Zhezhova', Sonja Jordeva ${ }^{1 *}$, \\ Sashka Golomeova Longurova', Stojanche Jovanov'
}

\author{
'University "Goce Delchev", Shtip, Faculty of Technology Shtip, \\ Republic of North Macedonia \\ *e-mail: silvana.zezova@ugd.edu.mk
}

\author{
Professional paper: \\ UDC: 677-037:613.4 \\ doi: $10.5937 /$ tekstind $2102021 Z$
}

\begin{abstract}
Medical textile is an extremely important subcategory of technical textile because it is covering a wide range of products. The term medical textile itself covers all types of textile materials that are used in the healthcare system for various purposes. Medical textile is also known as health textile and is one of the fastest growing sectors in the technical textile market. The growth rate of technical textiles in this area is due to constant improvements and innovations in both areas: textile technologies and medical procedures. Textile structures used in this field include yarns, woven, knitted and non - woven textile materials as well as composite materials reinforced with textiles. The number of applications is large and diverse, from simple surgical sutures to complex composite structures for bone and tissue replacement, hygiene materials, protective products used in operating rooms and in the process of postoperative wound treatment. The purpose of this paper is to emphasize the importance of technical textiles for medical, surgical and healtcare applications, to indicate which textiles are currently used in this field.
\end{abstract}

Keywords: textile structure, implantable materials, non-implantable materials, healthcare and hygiene, medical products.

\section{PRIMENA TEHNIČKOG TEKSTILA U MEDICINI}

Apstrakt: Medicinski tekstil je izuzetno važna potkategorija tehničkog tekstila jer pokriva širok spektar proizvoda. Sam pojam medicinski tekstil obuhvata sve vrste tekstilnih materijala koji se koriste u zdravstvenom sistemu u različite svrhe. Medicinski tekstil je poznat i kao zdravstveni tekstil i jedan je od najbrže rastućih sektora na tržištu tehničkog tekstila. Stopa rasta tehničkog tekstila u ovoj oblasti rezultat je stalnih poboljšanja i inovacija u obe oblasti: tekstilne tehnologije i medicinski postupci. Tekstilni materijali koje se koriste u ovoj oblasti uključuju pređe, tkanine, pletenine i netkani tekstil kao i kompozitni materijali ojačani tekstilom. Postoje mnogo raznovrsne mogućnosti primene medicinskog tekstila, od jednostavnih hirurških šavova do složenih kompozitnih struktura za zamenu kostiju i tkiva, higijenskih materijala, zaštitnih proizvoda koji se koriste u operacionim salama iu procesu tretmana postoperativne rane. Svrha ovog rada je da naglasi važnost tehničkog tekstila za medicinske, hirurške i zdravstvene usluge, da ukaže koji se tekstil trenutno koristi u ovoj oblasti.

Ključne reči: tekstilni materijali, implantabilni materijali, neimplantabilni materijali, zdravstvena nega i higijena, medicinski proizvodi.

\section{INTRODUCTION}

The term technical textiles includes all textile-based products used primarily for their performance or functional characteristics, not for their aesthetic and decorative properties. This means that technical textile is designed to feature wide spectrum of certain characteristics, making them suitable for application in extensive range of industries (automotive, aerospace, construction, protective gear, healthcare, and others). Depending on their purpose, these textiles are designed to have improved filtration, flexibility, durability, lightness, resistance and strength properties, amongst other features [1, 2]. 

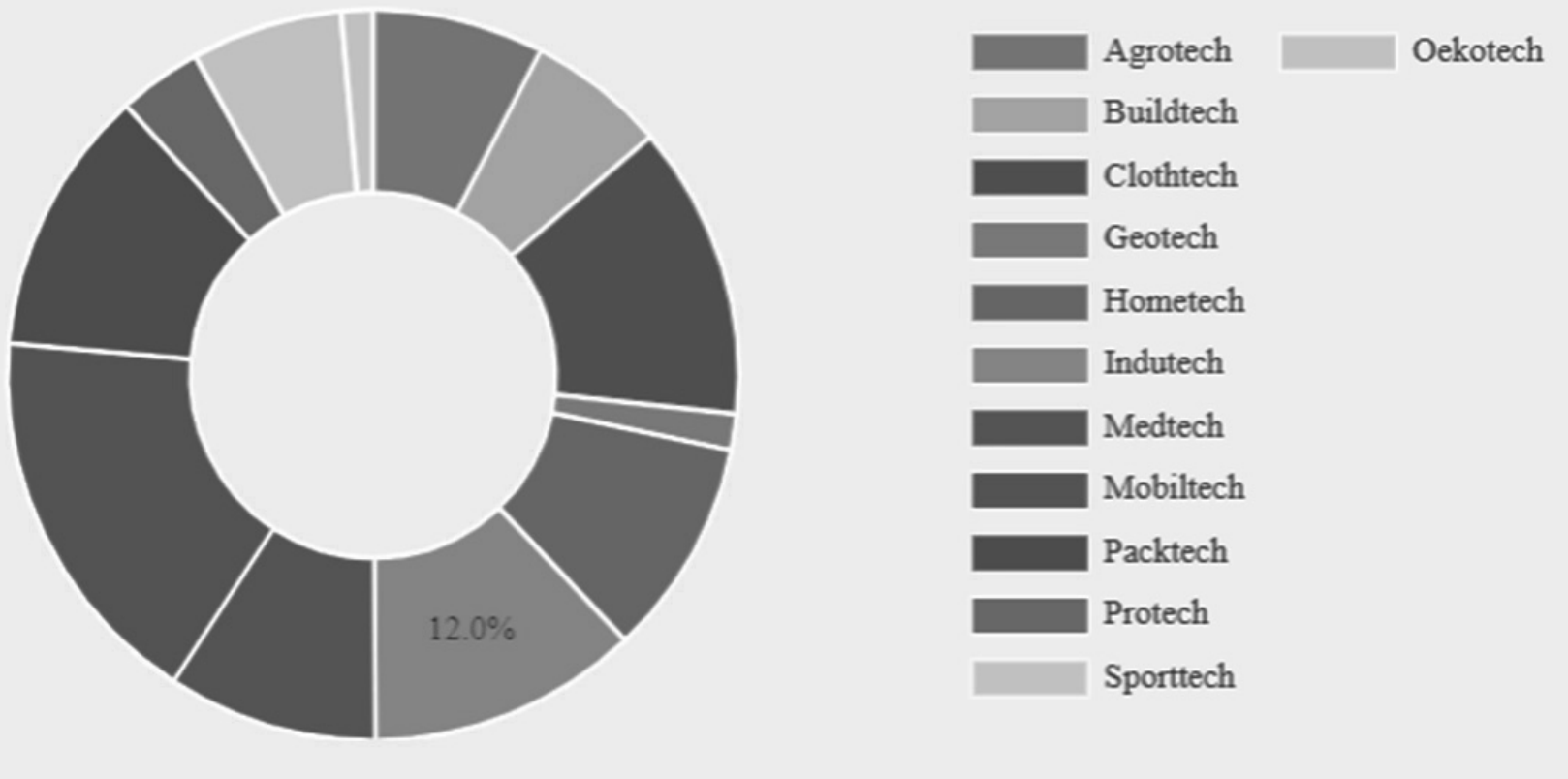

Figure 1: Global technical textiles market share, by product type, 2018 [4]

Technical textile products are usually classified into twelve groups, based on application and end-user industry, and is mainly comprised of (Figure 1): agro textiles (agrotech), construction textiles (buildtech), clothing textiles (clothtech), geo-textiles (geotech), domestic textiles (hometech), industrial textiles (indutech), medical textiles (meditech), textiles used in transport (mobiltech), packaging textiles (packtech), protective textiles (protech), sports textiles (sportech) and environmentally-friendly textiles (oekotech) $[3,4]$.

Technical textiles are considered to be the fastest growing sector of the textile industrial sector. The production of technical textiles makes up more than half of the production of textiles because the number of technical applications is significantly higher than the textile applications. The current volume market worldwide for technical textile is 193.9 billion in US dollars, and it's projected to reach $\$ 220.37$ billion by 2022 at CAGR $5.89 \%$. In terms of volume, this market was projected to reach 42.20 million metric tons by the end of 2020 , growing at a rate of around $4.68 \%$ [5]. Technical textile industry has witnessed remarkable growth in the past few years and this growth is estimated to increase in the next years.

Medical textiles is one of the most dynamically expanding and growing field in technical textiles [6]. An important and larger part of the products of the textile industry are used in the medical, health and hygiene sectors. The number of applications is large and diverse, from simple surgical sutures to complex composite structures for bone and tissue replace- ment, hygiene materials, protective products used in operating rooms and in the process of postoperative wound treatment. The degree of growth and application of technical textiles in this area is due to constant improvements and innovations in both areas: textile technologies and medical procedures. The healthcare and medical sectors offer the greatest opportunities for the development of the most sophisticated and valuable textile materials for different types of medical applications and represent one of the most important areas for stimulating production of technical textiles $[7,8]$.

\section{TEXTILE INTENDED FOR MEDICAL AND HEALTH CARE}

The term medical textile covers all types of textile structures that are used in the healthcare system for various purposes. The textile structures used include yarns (monofilament and multifilament), woven, knitted, braided and non-woven textile materials as well as textile reinforced composite materials.

The history of medical textiles goes back to thousands of years ago when the development of wound closures and sutures took place, but the "official" application began with the development of medical services [9]. With the development of new types of fibres and technologies for the production of linear and two dimensional textile structure, the application of textile materials for medical purposes is even more significant. Depending on the application of medical textiles, an appropriate choice of constituent 
elements can be made, starting from the type of polymers and fibres to the shape of the textile structure and the type of textile material.Textile fibres used for medical purposes differ from other conventional materials because they must meet certain standards and criteria, as follows [10]:

- Not to have toxic effects on the human body;

- Do not cause skin irritation or allergic reactions;

- Adequate mechanical properties (strength, elasticity, durability and etc.);

- Good absorption of moisture and water;

- Good air permeability;

- Biocompatibility;

- Bacteriostaticity;

- Antiviral properties;

- Ability to be sterilized;

The major requirements of textile material used in medical are absorbency, tenacity, flexibility, softness and biostability or biodegradability. By using suitable polymers in the production of textile fibers and materials the above requirements can be met. Different types of fibers obtained from natural and manufactured polymers can be used for the production of this type of textile materials. The most commonly used polymer fibrous materials for production of medical textiles are given in Table $1[11,12]$.

\section{CLASSIFICATION OF MEDICAL TEXTILE}

Medical textiles are an extremely important subcategory of technical textiles because they cover a wide range of products. Mainly four type of textile structures are used for production of medical textile products. These are woven, knitted, braided and nonwoven. The first three of these are made from yarns, whereas the fourth can be made directly from fibers, or even from polymers. Yarns are interlaced into fabrics by different mechanical processes (weaving, knitting and braiding). The characteristics and properties of each textile structure determine its suitability for a particular application. Woven fabrics are usually dimensionally very stable but less extensible and porous than other structures. The major advantage of knitted fabrics is their flexibility and inherent ability to resist unraveling when cut. A potential limitation of knitted fabrics is their high porosity. Braided structures can be designed using several different patterns, either with or without a core, and they are usually used for production of biodegradable and non-biodegradable surgical sutures, artificial ligament, artificial tendon, etc.

Table 1: Types of polymers for production of medical textile $[11,12]$

\begin{tabular}{|c|c|c|}
\hline Types & Origin & Fibers and polymers \\
\hline \multirow[t]{2}{*}{ Natural fibers } & Vegetable (cellulose) & $\begin{array}{l}\text { Cotton } \\
\text { Linen } \\
\text { Hemp }\end{array}$ \\
\hline & Animal (protein) & Silk \\
\hline \multirow{3}{*}{ Man made fibers } & $\begin{array}{c}\text { Artificial } \\
\text { (by transformation of natural } \\
\text { polymers) }\end{array}$ & $\begin{array}{c}\text { Regenerated cellulose (viscose, lyocell) } \\
\text { Proteins (collagen) } \\
\text { Alginate fiber } \\
\text { Chitin } \\
\text { Chitosan } \\
\text { Polylactide fiber } \\
\text { Polyglycolide fiber }\end{array}$ \\
\hline & $\begin{array}{c}\text { Synthetic } \\
\text { (from synthetic polymers) }\end{array}$ & $\begin{array}{c}\text { Polyamide } \\
\text { Polyester } \\
\text { Polypropylene } \\
\text { Polyurethane } \\
\text { Polytetrafluoroethylene } \\
\end{array}$ \\
\hline & $\begin{array}{c}\text { Inorganic } \\
\text { (from inorganic materials) }\end{array}$ & $\begin{array}{l}\text { Carbon } \\
\text { Glass } \\
\text { Metal }\end{array}$ \\
\hline
\end{tabular}


Non-woven textile materials have the greatest application for the production of medical textiles because they can produce disposable and cost effective products [13]. The properties of nonwoven fabrics depend on the characteristics of the constituent polymer or fiber and on the bonding process. There are numerous medical uses for nonwoven fabrics: bandages, absorbent pad, wipes, gowns, surgical caps and mask, etc. Analyzes show that nonwovens accounted for $64.29 \%$ of the global medical textile market in 2018 and is projected to grow at a fastest CAGR of $5.0 \%$ during the forecast period (2015-2025). The second largest segment is woven fabrics with $15.38 \%$ of global market volume in 2018 and is projected to reach 491.8 kilo tons by 2025 (Figure 2). Woven fabrics typically find their applications in hospital and surgical hosiery, different types of bandages, wound contact layer, plasters, artificial tendons, cardiovascular implants, etc. Knitted fabrics are used for cardiovascular implants and other applications used in surgical mesh, hernia repair, reconstructive and cosmetic surgery mesh and various other containment devices [14].

Also, another feature of the medical textile market is the growing proportion of textile-reinforced composite materials used in wound management products. This will mean the combination of textiles with such materials as films, foam and adhesives to form

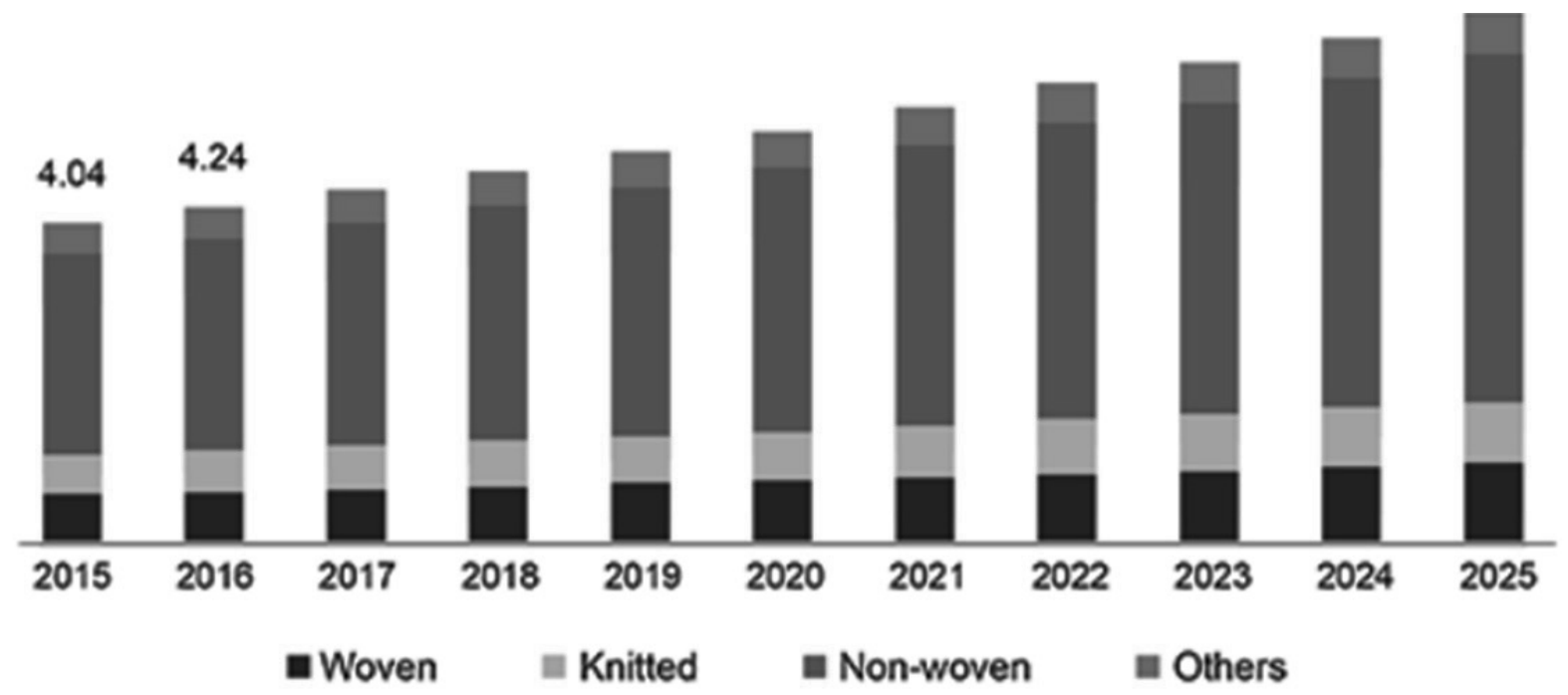

Figure 2: U.S. medical textile market, size by type of textile material, 2015-2025 (billion USD) [14]
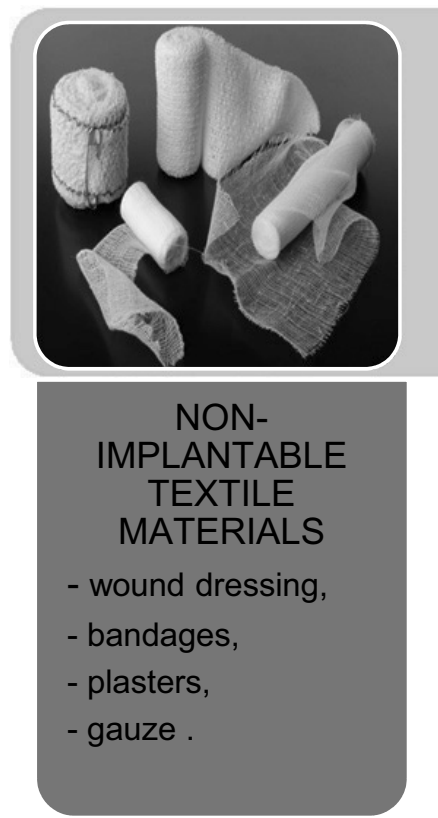

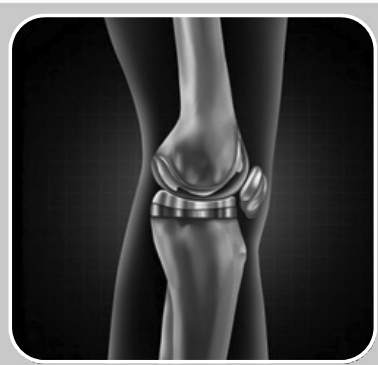

IMPLANTABLE TEXTILE MATERIALS

- surgical sutures,

- vascular grafts, - artificial implants, - artificial joints

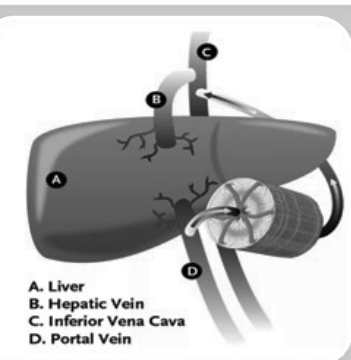

EXTRACORPORAL DEVICES

- artificial kidney, - artificial liver - mechanical lungs

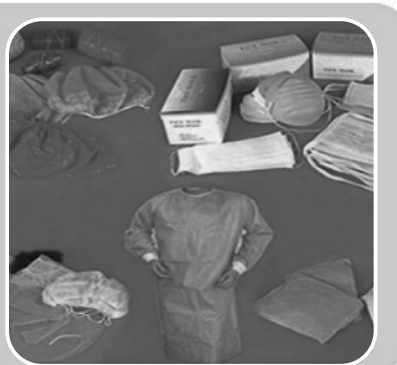

HEALTHCARE AND HYGIENE PRODUCTS

- surgical clothing - beddings,

- covers,

- cloths,

- sanitary napkins, - baby dipers,

Figure 3: Classification of medical textile by application $[15,16]$ 
structures for the treatment of wound and healthcare products.

Textile materials are used in a number of separate and specialized applications which can be categorized into 4 main areas of application (Figure 3): non - implantable materials, implantable materials, extracorporal devices and healthcare and hygiene products $[15,16]$.

\subsection{Non-implantable textile materials}

Non-implantable materials are used for external applications on the body, they are never implanted within the body. The function of these materials is to provide protection against infection, to absorb blood and body secretions, and in certain cases for use of medicaments in postoperative tretments etc. [17]. This type of material can, but does not have to be in contact with the skin. Some examples of non-implantable materials include wound care, bandages, plasters, orthopedic belts, pressure garments, etc. (Table 2). For production of these type of materials can be used different kind of textile fibers: cotton, silk, viscose, lyocell, collagen, polyester, polyamide, polypropylene etc.

Table 2: Types of fibers for non-implantable medical textiles and their application [16]

\begin{tabular}{|c|c|c|}
\hline Types of fibers & Types of textile materials & Application, products \\
\hline Cotton, viscose, lyocell & Non-woven & Absorbent pad \\
\hline $\begin{array}{c}\text { Alginate fiber, chitosan, silk, viscose, lyocell, } \\
\text { cotton }\end{array}$ & Woven, non-woven, knitted & Wound-contact layer \\
\hline $\begin{array}{c}\text { Cotton, viscose, lyocell, polyamide fiber } \\
\text { Cotton, viscose, lyocell, elastomeric fiber yarns }\end{array}$ & Woven, non-woven & Base material \\
\hline Cotton, viscose, lyocell, elastomeric fiber yarns & Woven, knitted, non-woven & $\begin{array}{c}\text { Simple non-elastic and } \\
\text { elastic bandages }\end{array}$ \\
\hline $\begin{array}{c}\text { Cotton, viscose, lyocell, } \\
\text { Polyester, elastomeric fiber yarns }\end{array}$ & Woven, knitted & Compression bandages \\
\hline $\begin{array}{c}\text { Cotton, viscose, lyocell, } \\
\text { polyester, polyurethane foam }\end{array}$ & Woven, non-woven & Orthopedic bandages \\
\hline $\begin{array}{c}\text { Cotton, viscose, lyocell, } \\
\text { polypropylene, polyester, }\end{array}$ & Woven, knitted, non-woven & Plasters \\
\hline $\begin{array}{c}\text { Cotton, viscose, lyocell, } \\
\text { alginate fiber, chitosan }\end{array}$ & Woven, knitted, non-woven & Gauze dressing \\
\hline Cotton & Woven fabrics & Lint \\
\hline Polylactide, polyglycolide, carbon fiber & Needle punched non-woven & Wadding \\
\hline $\begin{array}{c}\text { Viscose, cotton linters, wood pulp } \\
\text { Noffold }\end{array}$ \\
\hline
\end{tabular}

\subsection{Implantable textile materials}

Implantable materials are biocompatible and are used in effecting repair to the body whether it is wound closure (surgical sutures) or replacement surgery (soft tissue implants, orthopedic implants, cardiovascular implants). The soft-tissue implants are flexible strong materials commonly used to replace tendons, ligaments and cartilage in both reconstructive and corrective surgery [18]. In Table 3 are presented textile fibres and fabrics used for the implantable materials, and some of the areas of their application [16]. 
Table 3: Types of fibres for implantable medical textiles and their application [16]

\begin{tabular}{|c|c|c|}
\hline Types of fibres & Types of textile materials & Application \\
\hline \multicolumn{3}{|c|}{ Surgical sutures } \\
\hline Collagen, polylactide, polyglycolide & Monofilaments, braided & Biodegradable surgical sutures \\
\hline $\begin{array}{l}\text { Polyester, polyamide, polypropylene, } \\
\text { polyethylene, polytetrafluoroethylene }\end{array}$ & Monofilaments, braided & Non-biodegradable surgical sutures \\
\hline \multicolumn{3}{|c|}{ Soft tissue implants } \\
\hline $\begin{array}{l}\text { Polytetrafluoroethylene, polyethylene, } \\
\text { Polyester, polyamide, silk }\end{array}$ & Woven, braided & Artificial tendon \\
\hline Polyester, carbon, collagen & Braided & Artificial ligament \\
\hline Low-density polyethylene & Non-woven & Artificial cartilage \\
\hline Chitin & Non-woven & Artificial skin \\
\hline $\begin{array}{l}\text { Polymethyl methacrylate, } \\
\text { silicon fibre, collagen }\end{array}$ & & Eye contact lenses \\
\hline \multicolumn{3}{|c|}{ Orthopedic implants } \\
\hline $\begin{array}{l}\text { Silicone, polyacetyl fibre, polyethylene } \\
\text { fibre }\end{array}$ & & Artificial joints/bones \\
\hline \multicolumn{3}{|c|}{ Cardiovascular implants } \\
\hline Polyester, polytetrafluoroethylene & Knitted, woven & Vascular grafts \\
\hline Polyester & Knitted, woven & Heart valves \\
\hline
\end{tabular}

Table 4: Types of extra-corporeal devices [15]

\begin{tabular}{|c|c|c|}
\hline Types of fibers & Application & Function \\
\hline Hollow viscose & Artificial kidney & $\begin{array}{c}\text { Remove waste products from } \\
\text { patients' blood }\end{array}$ \\
\hline Hollow viscose & Artificial liver & $\begin{array}{c}\text { Separate and dispose of patients' } \\
\text { plasma and supply fresh plasma }\end{array}$ \\
\hline $\begin{array}{c}\text { Hollow polypropylene fiber, } \\
\text { Hollow silicon membrane }\end{array}$ & Mechanical lung & $\begin{array}{c}\text { Remove carbon dioxide from } \\
\text { patients' bloodand supplying fresh } \\
\text { oxygen }\end{array}$ \\
\hline
\end{tabular}

\subsection{Extra-corporeal devices}

Extra corporal devices are mechanical organs used to support the function of vital organs (kidney, liver, lung etc.). These devices are used for blood purification such as hemodialysis, hemofiltration, plasma-exchange and hemoadsorption. In Table 4 are presented the types of extracorporeal devices, fibers used for their production and their function.

\subsection{Healthcare and hygiene products}

An important area of medical textile is the healthcare and hygiene sector. They cover all those materials that are used for external application, protection and safety of the medical staff and patients. They are designed to either be washable or discarded after a single use. All fibers used in this product must be non-toxic, non-allergenic, noncarcinogenic and must be able to be sterilised without imparting any change in their physical or chemical characteristics [19]. Healthcare and hygiene products include (Table 5): hospital gowns and uniforms, clothing and wipes, surgical hosiery, masks, caps, hospital bed products etc. 
Table 5: Types of products for health protection and hygiene maintenance [15]

\begin{tabular}{|c|c|c|}
\hline Types of fibers & Types of textile materials & Application of the product \\
\hline Cotton, polyester, polypropylene & Non-woven, woven & Surgical gowns \\
\hline Viscose & Non-woven & Surgical caps \\
\hline Viscose, polyester, glass fiber & Non-woven & Surgical masks \\
\hline Polyester, polyethylene & Non-woven, woven & Surgical drapes and cloths \\
\hline Cotton, polyester, polyamide & Knitted & Surgical hosiery \\
\hline Cotton, polyester & Woven, knitted & Blankets \\
\hline Cotton & Woven & Sheets, Pillow cases \\
\hline Cotton, polyester, & Woven & Uniforms \\
\hline Polyester, polypropylene & Non-woven & Protective clothing \\
\hline Super absorbent fibers, wood fluff & Non-woven & Absorbent layer \\
\hline Polyethylene & Non-woven & Outer Layer \\
\hline Viscose, lyocell & Non-woven & Cloths, wipes \\
\hline
\end{tabular}

\section{MEDICAL TEXTILES MARKET}

The global medical textile market has been segmented into Europe (Germany, UK, France), North America, South America, Asia Pacific (China, Japan, India, South Korea), and the Middle East and Africa. North America collectively lead the medical textiles sector owing to remarkable growth in end-use businesses including Implantable goods and healthcare and hygiene products. Europe holds the second position in the global medical textile market. Asia-Pacific is viewed as a promising market for the global medical textile sector. This is owing to the growing incidence of diseases, wide-ranging need for innovative medical equipment, increasing application of the initial stages of diagnosis of conditions, and the increasing amount of healthcare centers. Asia-Pacific is expected to represent the fastest growing market for medical smart textiles goods during the forecast period.The Middle East \& Africa (MEA) region represents a relatively small share of the global medical textile market, owing to the poor economic conditions and the stringent government policies [19].

The global medical textile market is expected to reach USD 20.23 billion by 2022, according to a new

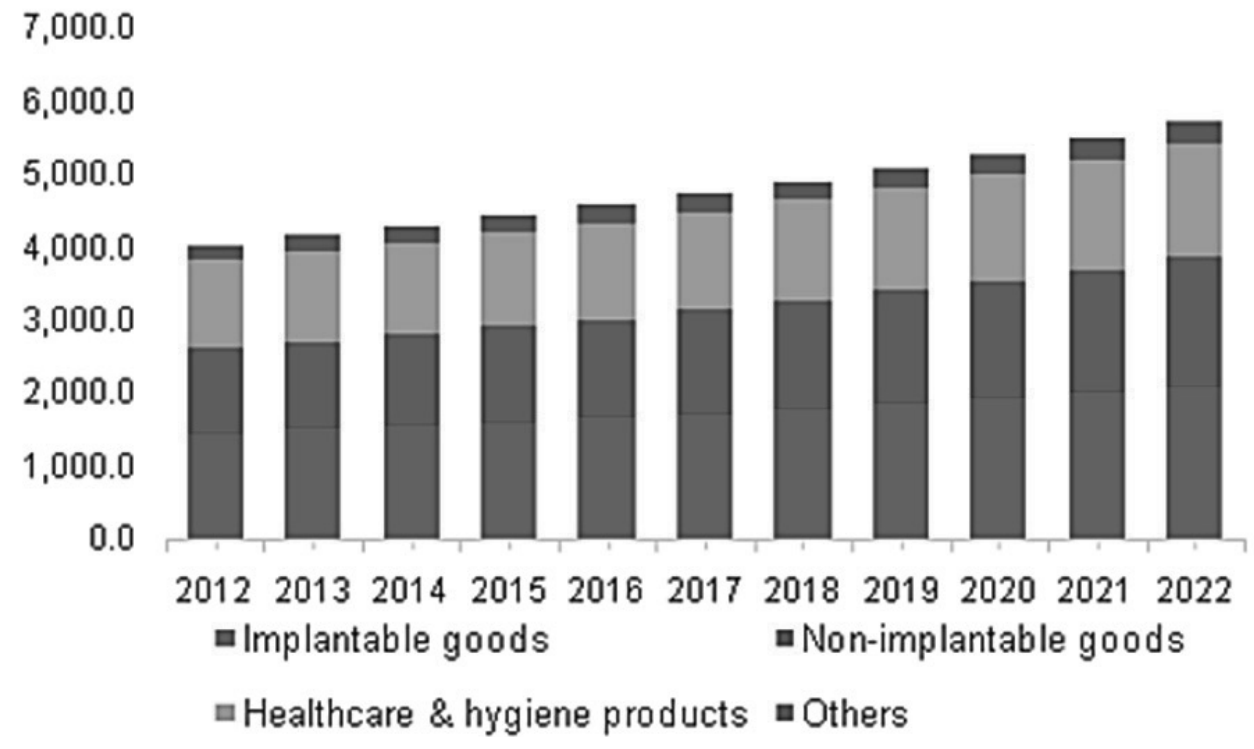

Figure 3: Europe medical textiles market revenue, by application, 2012-2022 (USD Million) [14] 


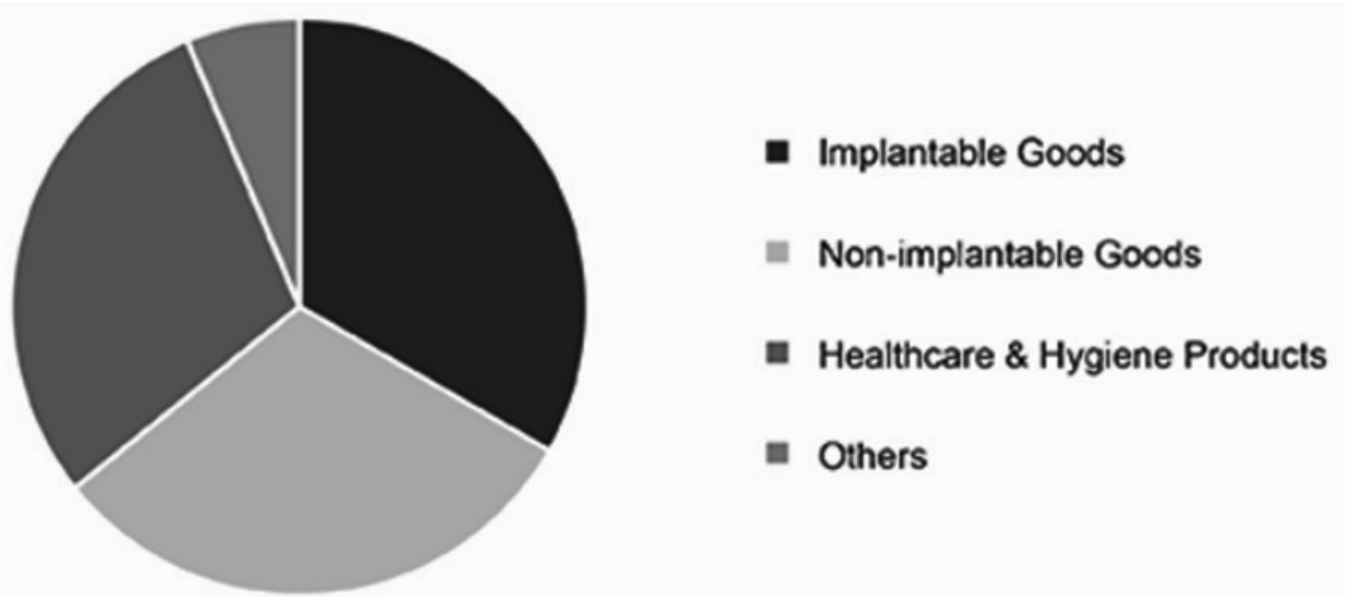

Figure 4: Global medical textiles market share, in terms of revenue, by application, 2018 (\%) [14]

report by Grand View Research, Inc. [20]. These predictions are primarily based on the increasing the number of elderly population, current technological advancements, increasing health awareness and strict legal regulations that require the use of medical textiles.

In terms of application, in 2018 implantable products had the largest share (33.20\%) in global revenues (Figures 3 and 4). The increase in the number of chronic diseases (coronary heart disease, cholesterol and hypertension), is expected to increase the consumption of implantable products. Non-implantable products accounted for $32.24 \%$ of the global market volume in 2018.

Although textiles are widely accepted for medical and surgical applications, new areas of application are constantly emerging. Fibre manufacturers produce different types of textile fibres and structures whose properties are adapted to the end application, whether the requirement is absorption, durability, flexibility, softness or biodegradability. Increasing income levels, an ageing population, rising health awareness, increasing disposable income are major factors considered to support the growth of the global medical textile market in the near future. Continued advances in medical science and textile technology, together with change of consumer demands, are expected to contribute to the growth of the medical textile market.

\section{CONCLUSION}

Medical textiles is one of the most important subcategory of technical textiles because they cover a wide range of products. Ranging from disposable products such as diapers and sanitary pads, various types of towels and wipes, to highly sophisticated or- gans and devices for blood filtration, prosthetics and orthopedic aids. The main attribute of a medical textile is that it should fulfil the purpose for which it was designed. Successful application of textiles in medicine implies interdisciplinary cooperation between scientists in the field of polymers, textile materials and medicine. With latest innovations in the field of textile technology, a wide variety of non-woven, knitted, and woven forms of the textile are gradually finding their way into a variety of medical procedures. The textile will be used in all extra corporal devices, external or implanted materials, healthcare and hygienic products. There is a dynamic increase in consumption of this type of textile products in the last 30-40 years and this trend is expected to continue in the future. The large number of health problems, the increase of awareness for better health solutions, the increase of available incomes, are expected to increase the demand for medical textiles in the future. In the coming period, a significant increase in demand for medical textiles in the sector of healthcare and hygiene in developing countries is expected. The medical textiles industry continues to grow at an alarming rate, with constant development of new smart technologies. Developments in the fields of the intelligent textile offer new opportunities for creating medical textiles with a higher level of functional characteristics and allow the development of completely new active medical textiles.

\section{REFERENCES}

[1] Horrocks, A. R., Anand, S. C. (2000). Handbook of technical textiles. Woodhead Publishing Limited, Cambridge England.

[2] Senthil Kumar, R., (2016). Textiles for Industrial Applications, CRC Press, Taylor \& Francis group. 
[3] Rasheed, A. (2020), Classification of Technical Textiles in Fibers for Technical Textiles, Springer.

[4] Technical textiles market size, share \& industry analysis, by product type, by fiber type, by product form, and regional forecast (2019-2026) (https:// www.fortunebusinessinsights.com/technical-textiles-market-102716/, available: 16/03/2021).

[5] Nawab, Y., Ahmad, S. (2020). Fibers for Technical Textiles, Springer International Publishing.

[6] Technical Textiles: An Overview (https://www. fibre2fashion.com/industry-article/826/technicaltextiles-an-over-view/, available: 10/04/2021).

[7] Rohani, A., Nouri, A., (2020). Medical textiles, Advances in Functional and Protective Textiles, 291-333

[8] Medical Textiles (https://www.technicaltextile.net/ articles/medical-textiles-2587/, available: 13/04/2021).

[9] Sharma, D. and Popli, H. (2018). An insight to medical textiles, World Journal of Pharmaceutical Research, 7 (13) 352-358.

[10] Qin, Y. (2016). Medical Textile Materials, Woodhead Publishing Series in Textiles.

[11] Akter, S., Yousuf Mohammad Anwarul Azim, A., Al Faruque, M. A. (2014). Medical textiles: significance and future prospect in Bangladesh, European Scientific Journal, 10(12).

[12] Sretkovic Lj. (2012). Tekstilni materijali za medicinsku namenu sa kombinovanim bioloskim dejstvom, Tehnološko-metalurški fakultet, Univerzitet u Beogradu.

[13] Urošević, S., Đekić, V. (2010). Stanje i procene daljeg rasta i razvoja sektora tehničkog i netkanog tekstila, Tekstilna industrija, 58(3), 20-28.

[14] Medical Textiles Market Analysis, Size and Growth to 2022.

(https://grandviewresearchinc.wordpress.com/ 2016/05/06/medical-textiles-market-analysis-sizeand-growth-to-2022/ available: 10/10/2020).
[15] Vaishnav, R. P., Sharma, B. R. (2015). Need of Development in Medical Textile Market in India International Journal on Textile Engineering and Processes, 1(2).

[16] Alistair, J. R., Subhash C. A., (2001). Medical textiles, Handbook of technical textiles, Bolton Institute, 407424.

[17] Parveen Banu, K., Subramaniam V., Pradeepa, P., (2014). Non implantable materials in medical textiles, International Journal of Current Research, 6(4), 6120-6123.

[18] Textile materials in implantable medical surgeries (http://indiantextilejournal.com/articles/FAdetails. asp?id=485/ available: 10/04/2021).

[19] Medical Textiles: Healthcare and Hygiene Products (https://www.fibre2fashion.com/industry-article/1704/medical-textiles-healthcare-and-hygiene/ available: 14/04/2021).

[20] Medical Smart Textile Market 2019 Global Analysis, Size, Growth, Key Players, Share, Revenue, Trends, Opportunities, And Regional Forecast To 2023 (https://www.medgadget.com/2019/07/medicalsmart-textile-market-2019-global-analysis-sizegrowth-key-players-share-revenue-trends-opportunities-and-regional-forecast-to-2023.html/ available: 22/03/2021).

Primljeno/Received on: 19.04.2021.

Revidirano/ Revised on: 11.05.2021.

Prihvaćeno/Accepted on: 13.05.2021.

(c) 2021 Authors. Published by Union of Textile Engineers and Technicians of Serbia. This article is an open access article distributed under the terms and conditions of the Creative Commons Attribution 4.0 International license (CC BY) (https://creativecommons.org/licenses/by/4.0/) 